\title{
A study on biochemical composition of the sting gland (poison gland) and the reservoir (poison sac) of the dwarf honey bee Apis florea F. workers
}

\author{
Neelima R. Kumar and Anita Devi* \\ Department of Zoology, Panjab University, Chandigarh, INDIA \\ *Corresponding author. E-mail: anniekadian@gmail.com \\ Received: October 26, 2013; Revised received: February 9, 2014; Accepted: April 1, 2014
}

\begin{abstract}
The glands associated with the sting apparatus of worker honey bee Apis florea produce Venom which is known to be composed of a wide spectrum of biomolecules ranging from biogenic amines to peptides and proteins. The Venom apparatus showed the presence of two important associated exocrine glands i.e. Venom gland and Dufors gland. The secretions of both glands are apocrine and are released into the lumen to be stored in the venom sac. The presence of some exocrine cells in the distal part of venom sac which is otherwise known to only store the component of Venom gland led to the present study. The present study that there were considerable differences in the biochemical composition of Venom gland and Venom sac secretions of Apis species The concentration of lipids (Sting gland $=1.423 \pm 0.0001$ and Reservoir $=1.21 \pm 0.0067$ ), proteins (Sting gland $=0.440 \pm 0.0226$, Reservoir $=0.390 \pm$ 0.032 ), activity of acid phosphatase (Sting gland $=112.09 \pm 21.100$, Reservoir $=22.63 \pm 1.467$ ) and hexokinase (Sting gland $=20.7 \pm 4.016$, Reservoir $=10.66 \pm 2.465$ ) was found to be more in case of Venom gland while cholesterol(Sting gland $=0.138 \pm 0.0161$ reservoir $=0.324 \pm 0.00323$ ), glucose (Sting gland $=189 \pm 1.31$, Reservoir $=321 \pm 7.19$ ), free amino acids, and activity of alkaline phosphatase (Sting gland=21.03 \pm 0.195 Reservoir $=22.4 \pm 0.685$ ) was more in Venom sac. Glycogen was absent in both Venom gland and Venom sac of Apis species as confirmed by the absence of glucose-6-phosphatase activity. It is established from the present study that Venom sac also secretes various biochemicals and enzymes which are added to the total Venom.
\end{abstract}

Keywords: Apis florea, Dufors gland, Honeybee, Venom, Venom gland

\section{INTRODUCTION}

The main gland associated with the sting in workers of Apis florea is the Venom gland. It lies in the posterior part of the abdomen and is in the form of a pair of long tubules. Before entering the poison sac these tubules combine into a common duct. This duct joins the anterior end of poison sac, where the Venom is stored until required. The poison sac tapering in shape at posterior end discharges directly into the bulb of the sting shaft. There are no valves or closing mechanisms. Venom is expelled by the action of the bufferfly valves associated with the bulb. The composition of bee venom has been a subject of interest for a long time, since venom can trigger serious allergic reactions in humans. Its active ingredients have been worked upon by various scientists and found to contain various enzymes, specific toxins, or other bioactive molecules. Bee Venom is haemorrhagic and contains apamine, melittin, phospholipase, hyaluronidase. The Venom also contains mineral substances, volatile organic acids, formic acid and some antibiotics.

Venom is one of the products of honey bee, which is important component in the pharmaceutical industry. It is used in the treatment of various health conditions such as pain (Kim et al., 2003), cancerous tumours
(Russell, 2004), skin diseases, arthritis and rheumatism (Putz, 2006), and the wide use of apitoxin (honey bee venom) is giving rise to a new branch of medicine referred to as Apitherapy (the medical use of honey bee products). Moreover the presence of some exocrine cells in the distal part of venom sac which is otherwise known to only store the component of Venom gland led to the present study.In the recent reports, Abreu et al. (2010) suggested the presence of secretory cells in the proximal part of the reservoir. The final toxin is a mixture of secretions from the two parts of the venom apparatus. Keeping the above in view, the present investigation was undertaken to determine the macromolecules like proteins, carbohydrates, lipids, aminoacids and acid and alkaline phosphatase enzymes constituting the secretion of the poison gland (Sting/Venom gland) and poison reservoir (Venom sac) in workers of Apis florea.

\section{MATERIALS AND METHODS}

Study material: The honey bee A. florea workers taken for the present study were collected from the nests made on branches of bushes, hedges and trees from village Khuda Lahora near Panjab University, Chandigarh. 
Sample collection: A random sample of worker bees was collected from the hive. The sting gland was gently pulled out along with the sting. The sting gland was put on a slide in a drop of saline. The chitinous structures were carefully removed with a needle. The glands and reservoir were separated with the help of a blade. Glands and reservoir were separately homogenized. Seventy glands and seventy reservoirs were pooled in different homogenizing tubes in $1.0 \mathrm{ml}$ of saline and electrically homogenized. Samples S (sting gland) and R (Reservoir) were prepared for the gland and reservoir respectively.

Analysis of biochemical parameters: The different macromolecules were estimated by standard methods viz. glucose by Somogyi-Nelson's method (1945), glycogen by Seifter's method (Seifter et al., 1950), lipids by the method of Fringes and Dunn's (1970), cholesterol by Zalatki's method (Zalatki et al., 1953) and proteins by Lowry's method (Lowry et al., 1951). Amino acid assay was done by Paper chromatography (Swarup et al., 1981). Both acid and alkaline phosphatases were estimated by following the method of Bergmeyer (1963), glucose- 6- phosphatase by the method of Freeland and Harper (1959) and hexokinase by the method of Crane and Sols (1953).

\section{RESULTS AND DISCUSSION}

The intent of the present investigation was to obtain more information about the Venom producing gland. The results of various biochemical tests performed on the two compartment of the Venom gland of honey bee A. florea are presented in figs. 1-4 and table 1.

$\mathrm{Rf}$ (Retardation factor) value was calculated using the formula:

$\mathrm{Rf}=$ distance moved by the substance from origin / distance moved by solvent from origin

The Venom apparatus in the honey bee is located in the posterior portion of the abdomen, between the rectum and ovaries of workers. It consists of a secretary filamentous region, connected to a reservoir at its distal end, in which the Venom is stored (Kerr and Lello, 1962; Lello, 1971 and 1976). The composition of bee Venom has interested scientists mainly because of its medicinal significance. Banks and Shipolini (1986) reported that bee Venom was essentially protein. In the present study, it was observed that protein concentration was more in the poison gland than in the reservoir of the A. florea workers as shown in the fig. 1.

According to Dotimas and Hider (1987), the Venom is a complex mixture of enzymes, polypeptides and low molecular weight components. Low molecular weight compounds present in bee Venom are amino acids, catecholamines, sugars and minerals. Bousquet et al. (1979) reported 55 enzymes in the bee Venom, Vsenom sac, sacless whole body extract and whole body commercial extracts.

Saraf (2005) reported that there was highest amount of protein in the Venom apparatus of $A$. dorsata. Stinging accidents also report that the stings of $A$. dorsata are more painful and toxic than the stings of other species of Apis. The results of Paper chromatography for free amino acid analysis of the Venom extract from Venom gland (poison gland) and Venom sac (reservoir) (Table 1) indicated that there were four amino acids in case of poison gland which were histidine, Serine, DL-Aspartic Acid and DL-Valine. There were five amino acids spotted in reservoir which were L- Lysine, Glycine, L-Proline, glutamic acid and DL-tryptophan.

Acid phosphatases are the enzymes which act at low $\mathrm{pH}$ and are used to free attached phosphate group from other molecules during digestion. According to the findings of Abreu et al. (2010) among the hydrolytic enzymes, the highest activity in the bee venom was recorded for acid phosphatase, which was cytochemically detected throughout the length of secretory filament and surrounding the canaliculi of the distal region of reservoir. The acid phosphatase was considered to be a typical secretion product, since it was present in the cytoplasm as well as in the canaliculi of the secretory cells. Alkaline phosphatases are responsible for removing the phosphate group from many molecules such as nucleotides and proteins at high $\mathrm{pH}$. The ultrastructural observations demonstrated its presence in the secretory vesicles and nuclei of the Venom gland secretory cells. Venom alkaline phosphatase was found to be temperature dependent (Mraz, 1982).

The present study revealed that acid phosphatase was more in poison gland as compared to be in the

Table 1. Amino acids identified in the homogenized sample of sting gland and reservoir of A. florea workers.

\begin{tabular}{|c|c|c|c|c|c|c|c|c|}
\hline \multirow[t]{2}{*}{ S.N. } & \multicolumn{4}{|c|}{ Sting gland } & \multicolumn{4}{|c|}{ Reservoir } \\
\hline & Rf value & Colour & $\begin{array}{c}\text { Colour } \\
\text { intensity }\end{array}$ & $\begin{array}{c}\text { Amino } \\
\text { acid }\end{array}$ & Rf value & Colour & $\begin{array}{l}\text { Colour } \\
\text { intensity }\end{array}$ & $\begin{array}{c}\text { Amino } \\
\text { acid }\end{array}$ \\
\hline 1 & 27 & Purple grey & ++ & Histidine & 22 & Purple light & ++ & Alanine \\
\hline 2 & 37 & Purple & +++ & Serine & 33 & Purple light & +++ & Lysine \\
\hline 3 & 51 & Purple light & ++ & $\begin{array}{l}\text { Aspartic } \\
\text { acid }\end{array}$ & 48 & Purple & ++ & Glysine \\
\hline 4 & 62 & Purple & + & Valine & 59 & Yellow & ++ & Proline \\
\hline 5 & --- & --- & --- & --- & 66 & Purple pink & ++ & Tryptophan \\
\hline
\end{tabular}

Colour intensity shows amino acids (+=slightly present, $++=$ Moderate, $+++=$ Abundant, $-=$ absent) 


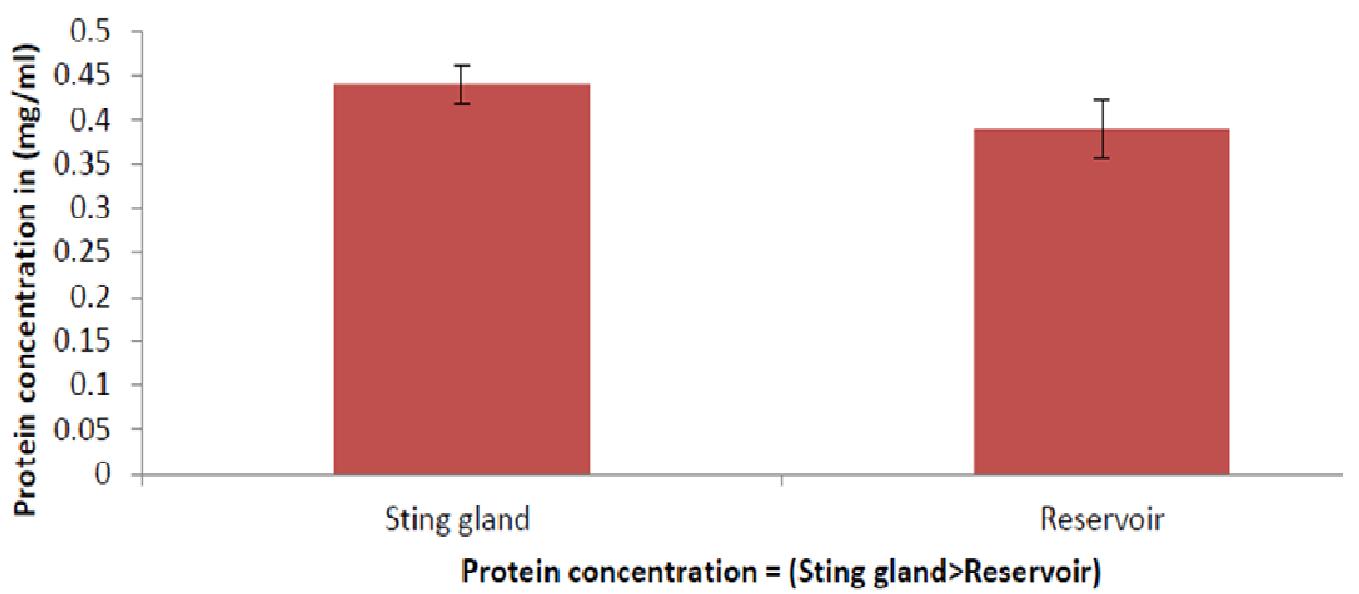

Fig. 1. Concentration of protein in sting gland and reservoir.

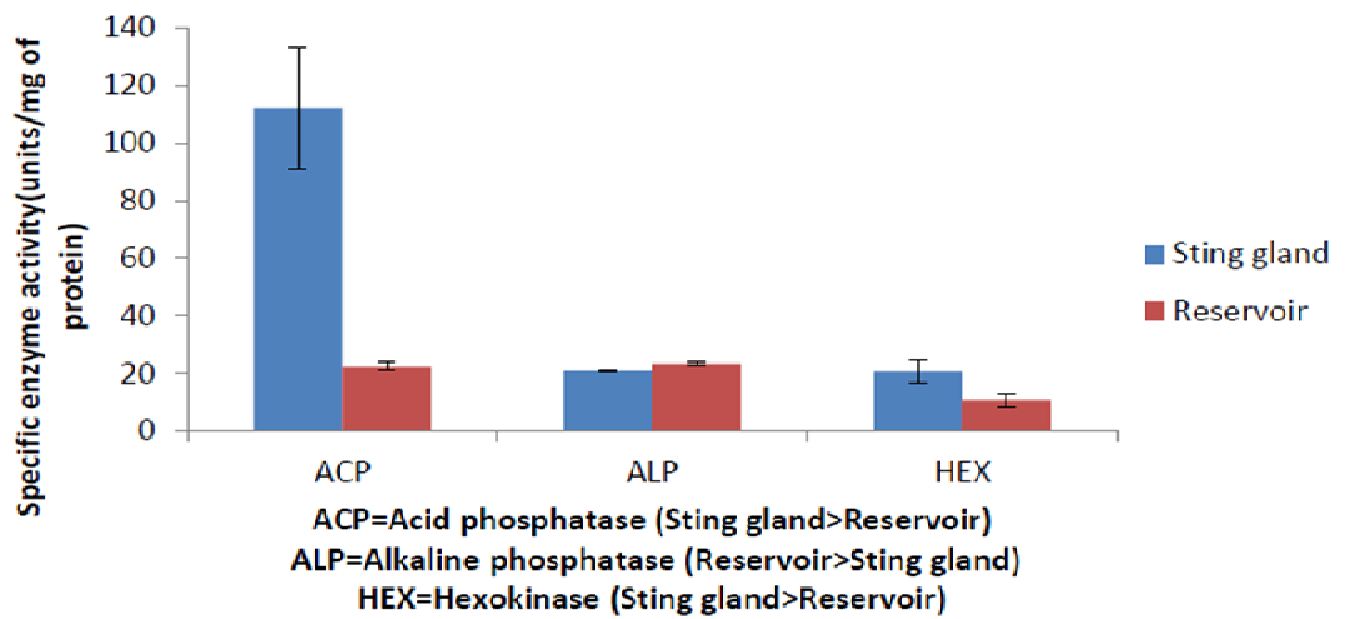

Fig. 2. Activities of different enzymes in sting gland and reservoir.

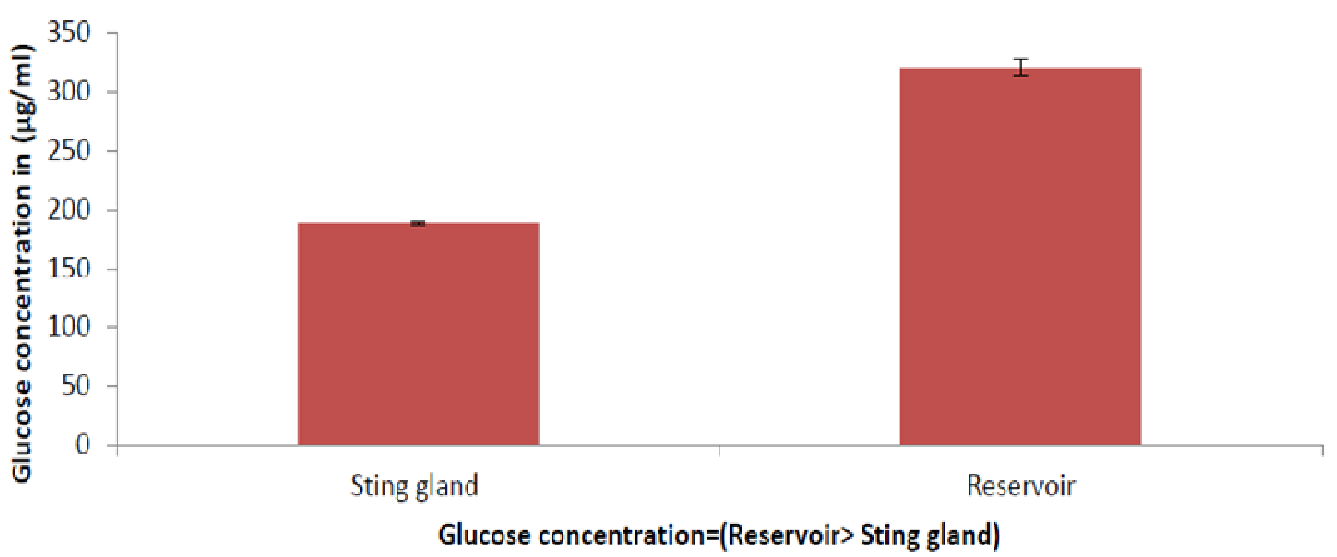

Fig.3. Concentration of glucose in sting gland and reservoir.

reservoir. On contrary, the activity of alkaline phosphatase was found to be more in the reservoir than in the poison gland (Fig.2). Hexokinase and glucose-6phosphatase are the enzymes which cause phosphorylation and dephosphorylation of 6 carbon compounds respectively. In present study, the enzyme activity of glucose-6-phosphatase could not observed in the poison gland or reservoir of the honey bee. This is in accordance with earlier studies where glucose-6phosphatase was not observed in any venom secretion 


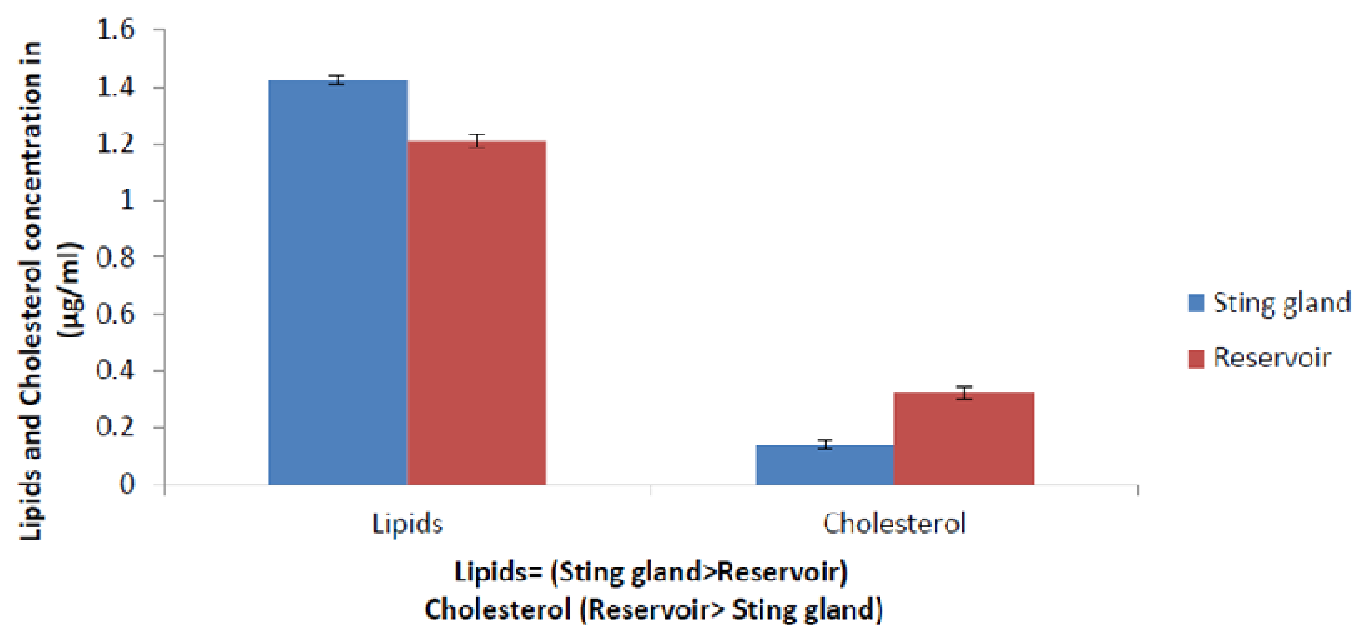

Fig.4. Concentration of lipids and cholesterol in sting gland and reservoir.

of honey bee (Ruiz-Amil, 1962).

The activity of hexokinase as shown in fig. 2 was observed to be more in the poison gland than in the reservoir. According to Crane (1990) bee venom comprised $88 \%$ water. The glucose, fructose and phospholipid content of the Venom were similar to those in the bee's blood. In present study, estimation of glucose in the two compartments of the venom apparatus revealed higher glucose content in the poison gland than in the reservoir (Fig. 3). This finding coupled with the greater activity of hexokinase in the poison gland suggests greater secretory activity of the filamentous gland as compared to the reservoir. Other workers have also suggested that the poison gland is the principle contributing structure for bee Venom. Glycogen was not detected in either the poison gland or reservoir of the A. florea. This observation is supported by absence of glucose-6-phosphatase activity in the two compartments of the venom apparatus. The concentration of total lipids was more in the poison gland while cholesterol was more in the reservoir (Fig. 4.). This finding gets support from the suggestion that the secretory cells of the reservoir probably contribute to the synthesis of steroid pheromones of alarm/ warning or defenses secreted along with Venom.

\section{Conclusion}

It was observed that there were considerable differences in the composition of Venom gland and Venom sac secretions of Apis species. Except lipids, proteins, acid phosphates and hexokinase all other contents were found maximum in the Venom sac because In Venom sac; it comprises the secretions of venom gland as well as the secretion of some of the secretory cells of the venom sac which are added to the total venom. Lipids are less in Venom sac because they are utilized by insects in forming some of their steroid hormones (pheromones) and some other physical activities are done by using proteins, and because Venom gland is acidic in nature so acid phosphatase enzyme is more in Venom gland. The greater activity of hexokinase in the poison gland suggests greater secretory activity of the filamentous gland (Venom gland) as compared to the reservoir (Venom sac). Glycogen was absent in both venom gland and Venom sac of Apis species as confirmed by the absence of glucose-6-phosphatase activity. It is established from the present study that Venom sac also secretes various biochemicals and enzymes which are added to the total Venom.

\section{REFERENCES}

Abreu, R.M.M., Silva de Moraes, R.L.M. and Camargo-Mathias, M.I. (2010). Biochemical and cytochemical studies of the enzymatic activity of the venom glands of workers of honey bee Apis mellifera $\mathrm{L}$ (Hymenoptera: Apidae). Micron, 41:172-175.

Banks, B.E.C. and Shipolini, R.A. (1986). Chemistry and pharmacology of honey bee venom In:Venoms of the hymenoptera: biochemical, pharmacological and behavioral aspects. (Piek $\mathrm{T}$ ed.) Academic Press London. pp, 89-94.

Bergmeyer, H.U. and Bernt, E. (1963). In: Methods of Enzymatic Analysis. (Bergmeyer, H.U ed.) Academic Press, New York. pp, 384-388.

Bousquet, J., Marty, J.P., Clauss, C. and Michael, F.B. (1979). Enzymes of bee venom sac and whole body. Ann. Allergy, 43:110-114.

Crane, E. (1990). Bees and beekeeping: science practice and world resources. Cormstock Publ Ithaca, NY USA. pp, 593.

Crane, R.K. and Sols, A., (1953). The association of hexokinase with particulate fractions of brain and other tissue homogenates. J. Biol. Chem., 203: 273-292.

Dotimas, E.M. and Hider, R.C. (1987). Honey bee venom. Bee world, 68(2): 51-70.

Freedland, R. A. and Harper, A. E. (1959). Metabolic adaptations in higher animals: The study of metabolic pathways by means of metabolic adaptations. J. Biol. Chem., 234:1350-1353.

Fringes, C.S. and Dunn, R.T. (1970). A colorimetric method for determination of total serum lipids based on the sulphophospho-vanillin reaction. Americ. J. Clin. Pathol., 53: 89-91. 
Hermann, H.R. and Blum, M.S. (1966). The morphology and histology of hymenopterous poison apparatus. Ann. Ent. Soc. Am., 59: 397-409.

Kerr, W.E. and Lello, E. (1962). Sting glands in stingless bees: A vestigial character (Hymenoptera: Apidae). Journal of the New York Entomological Society, 70(4): 192-214.

Kim, W.H., Kwon, B.Y., and Ham,( 2003). Acupoint stimulation using Bee Venom attenuate Formalin-Induced pain behavior and spinal cord fos expression in rats. J. Vet. Med .Sci., 65(3): 349-355.

Lello, E. D. (1976). Adnexal glands of the sting apparatus in the bees: Anatomy and histology V (Hymenoptera: Apidae). J. Kansas Entomol. Soc., 49(1): 85-99.

Lello, E.D. (1971). Adnexal glands of sting apparatus of bees: Anatomy and histology (Hymenoptera: Colletidae and Andrenidae). J. Kansas Entomol. Soc., 44: 5-13.

Lowry, O.H., Rosebrough, N.J., Farr, A.L. and Randell, R.J. (1951). Protein measurement with folin phenol reagent. J. Biochem, 193: 65-275.

Mraz, C. (1982). Bee venom for arthritis - an update. Amer. Bee J., 122: 121-123.

Putz, M. (2006). Antitumour action and immune activation through cooperation of bee venom secretory phospholipase A2 and Phosphatidyl inositol- $(3,4)-$ bisphosphate. Cancer immunol. Immunother., 55 (11):1374-1383.

Ruiz-Amil, M. (1962). The hexokinase of the honey bee. $J$. Inst. Physio., 8(3): 259-265.

Russell, (2004). Cytotoxic properties of immune conjugates containing melittin like peptide against prostate cancer: in vitro and in vivo studies. Cancer Immunol. Immunother., 53(5):411-421.

Saraf, M. (2005). Biochemical comparison of the sting gland of Honey bees. Dissertation submitted to the Panjab University, Chandigarh in the partial fulfillment of the requirements for the degree of M.Sc. (Hons. School) in Zoology.

Seifter S Seymour S Novic, E Muntwyler, E. (1950). Determination of glycogen with Anthrone reagent. In: Methods in Enzymology, 3: 35-36.

Somogyi, M. and Nelson, N. (1945). A photometric adaptation of the Somogyi method for the determination of glucose. J. Biol. Chem., 153: 375-379.

Swarup, H., Pathak, S.C. and Arora S. (1981). Laboratory techniques in modern biology. Kalyani publishers, New Delhi.

Zalatki, A., Zak, B. and Boyle, A.J. (1953). A new method for direct determination of serum cholesterol. J. lab Clin. Med., 41: 486-492. 